\title{
The urban dynamics of financial services: centralities in the metropolis
}

A dinâmica urbana dos serviços financeiros: centralidades na metrópole

\begin{abstract}
The objective of this paper is to develop arguments that compare the dynamics of financial capital and urban space. It is first argued that financial services follow a concentration-centralization logic, with highly specialized services being offered at central places in urban space, and less complex services with a more dispersed pattern. This characteristic simultaneously promotes a centralized-deconcentration effect on the urban structure: the dispersal of services and urban amenities reduces transport costs and improves urban balance in a few places, while complex services are usually highly centralized, therefore promoting unbalanced (centre-periphery) urban development. In order to understand the balance between these two effects, this paper proposes a preliminary investigation that examines the localization of banks, income and other socioeconomic features in the metropolitan area of Belo Horizonte, in Brazil.
\end{abstract}

\section{Keywords}

banking services; agglomeration; centralization; urban dynamics.

JEL Codes G21; O16; O21; R12; R51.

\author{
Anderson Cavalcante \\ Universidade Federal de Minas Gerais \\ Renan P. Almeida \\ Universidade Federal de Minas Gerais \\ Nathaniel Baker \\ Clarion Associates
}

\section{Resumo}

O objetivo deste artigo é desenvolver argumentos que comparam a dinâmica do capital financeiro e o espaço urbano. Em um primeiro momento argumenta-se que os serviços financeiros seguem uma lógica de centralização, com serviços altamente especializados sendo oferecidos em lugares centrais no espaço urbano enquanto serviços menos complexos seguem um padrão de maior dispersão. Esta característica promove simultaneamente um efeito de desconcentração-centralizada na estrutura urbana: se por um lado a dispersão de serviços e amenidades urbanas reduz custos de transporte e melhora o equilibrio urbano em alguns lugares, usualmente os serviços complexos, por outro lado, são altamente centralizados, promovendo desenvolvimento urbano desequilibrado (centro-periferia). Para entender o equilíbrio entre estes dois efeitos, este artigo propõe uma análise preliminar da localização de bancos em função da renda e outras características socioeconômicas da Região Metropolitana de Belo Horizonte.

\section{Palavras-chave}

serviços bancários; aglomeração; centralização; dinâmica urbana.

Códigos JEL G21; O16; O21; R12; R51. 


\section{Introduction}

Many models of urban growth, which assume a constant outward expansion from a city core, have succumbed to an urban reality that is much more varied and complex. The spatial organization of cities reflects cultural, social, political and economic patterns which, viewed through the lens of time, are in constant motion. Taken altogether, the latter characteristics project the contemporary urban spatial structure as a result of a complex and dynamic system which responds to forces that are simultaneously competitive and complementary. These movements have altered the urban infrastructure and the conversion of land use, changing the urban footprint. The urban centers present, as a clear example of the interrelation between those forces, development dynamics marked by spaces of centralized deconcentration. These dynamics suggest that a process of deconcentration usually manifests itself in the emergence of other multifarious centralities, mostly through the clearing out of some areas and subsequent growth of others, in a typical center-periphery process.

The consolidation of specific places in the urban area occurs without any socially desirable planning, as a by-product of the capitalist logic of production, which is led by the effects of globalization on regional and urban inequalities throughout the world. Multiple studies on urban development have contemplated sanitary, health, education, and environmental sustainability. Very few, however, have been devoted to the comprehension of the financial dynamics of urban development. It is now fully acknowledged that financialization processes have gained greater significance in the last three decades, in a context of growing financial relationships between households and firms and an increasing use of financial services that leaves financialization with greater shares of revenue. If one suggests that financialization has regional roots, then urban areas can also be thought of as influenced by the logic of financial capitalism. Therefore, the urban space must change in accordance with increasingly unequal financial trends, which in turn must be considered in order to understand urban development and the preparation of cities' development plans.

Financial capital conquers new spaces, mimicking its valuation objectives, and generating an urban dynamic that increasingly promotes inequalities. Thus, the objective of this paper is to elaborate on this perspective, offering arguments comparing the dynamics of financial capital within the urban space. It will first be argued that financialization follows a cen- 
tralization logic, with highly specialized services being offered at central places in the urban space, and less complex services with a more dispersed pattern. This characteristic promotes a centralization-deconcentration effect on the urban structure: the dispersal of services and urban amenities reduces transport costs and improves urban balance in a few places, while complex services, often of speculative nature, are more highly centralized, promoting unbalanced (center-periphery) urban development. In order to understand the balance between these two effects, this paper provides an empirical study over localization of banks, land valuation and social characteristics in the metropolitan area of Belo Horizonte, in Brazil.

Section 2 discusses location theory and the dynamics of urban growth. In this context, the emergence of new centralities and the suburbanization process are presented and summarized. Then, section 3 establishes the theoretical link between urban growth, centrality and financialization. Section 4 illustrates empirical findings using the Metropolitan Region of Belo Horizonte $(\mathrm{MRBH})$ as a case study, and section 5 concludes the paper concatenating the urban planning implications of financialization and urban growth.

\section{Dynamics of urban growth and centrality}

This section revisits urban growth and location theories in order to provide a panorama of the relevant literature and introduce theories and approaches regarding the location of financial services and its contribution to urban growth. Given that the metropolis is the primary subject of our study, we begin by introducing location theories that explain inter-urban growth thus providing a better understanding of intra-urban growth within the metropolis and the importance of centralities to this structure. In the second part of this section, we discuss the phenomenon of growth in new urban centralities, emphasizing the process of suburbanization which has been developing far from the old downtown, and presenting multiple taxonomies to this process.

\subsection{Location and urban growth theories revisited}

One of the most well defined stylized facts in Economics is the tendency toward spatial concentration of people and productive activities. The di- 
versity of such agglomerations might be studied through the perspective of an urban hierarchy: on one side are highly diversified metropolitan economies like New York, London, and São Paulo; on the other side, more specialized economies, such as Manchester during the Industrial Revolution, Ipatinga and Youngstown during the Fordist Era and some mono-industrial cities spread from East China to Southeast Brazil up to the present day, and all the export-driven economies. Once the urban center is constituted by a process of agglomeration of productive activities, the city becomes the locus for reproduction of capital, in such a way that its relative size becomes the main materialization of agglomeration economies through the combination of sectors that form its economic base.

From the Economics' point of view, agglomeration economies are the main driver of the existence of cities. Three main factors affecting the decisions of firms and individuals can be summarized (Parr; Budd, 2000): a) Economies of Location (Marshall, 1890), whereby firms can benefit from the existence of a local pool of specialized productive factors (e.g. skilled labor, technical information); b) Economies of Urbanization - also well-known as Jacobian externalities - providing diversification and cross-fertilization of ideas that firms need; and c) Economies of Complex Activities, defined as connections among the economies' supply chains (warehousing, transportation, and distribution of goods). Just to make clearer, economies of scale are usually defined by an increase in activity at decreasing unit costs, while economies of scope involve reductions in costs from the joint-production of two or more goods. Economies of complexity refer to the sharing of different stages or processes of production by firms.

Jacobs (1969) created the hypothesis that agglomeration economies are the trigger to the innovation capacity of local economic actors, resulting in the increase of production efficiency and expansion of the export base of the urban center - or, more precisely, the substitution of exports. The export-base model (North, 1955) explains the growth of a city in conjunction with economic development of its "base", which is constituted by productive activities exporting to the rest of the country or abroad. The city also has specific production directed to the local market. However, it is its export-base which ultimately drives growth.

More recently, the combination of technological expertise and monetary gains has also been the focus of another branch of the literature, including, for example, the phenomenon of industrial districts. Some 
important references include Becattini and Rullani (1995), Maillat (1995), the so-called "Californian School of Economic Geography" (Scott, 1986; Storper, 1995) and the work of Michael Porter on the competitiveness of nations. Porter (1990) reiterates the importance of economies of location, arguing that geographically concentrated knowledge spillovers in a specialized industry stimulate growth. However, unlike MAR externalities, it is the local competition that favors growth, since competition stimulates imitation and, in turn, triggers innovation.

Since the significant suburbanization process that began worldwide after WWII, many models from the Regional Science tradition became less relevant in attempting to explain urban growth. Specifically, the Alonso-Muth-Mills (AMM) model was not able to cope with a polycentric city. Facing this challenge, but trying to support the neoclassical epistemology applied to the urban space, Henderson (1974) endeavored to develop a model capable of accounting for the polycentric nature of the Post-Metropolis ${ }^{1}$. He explained that urban centers developed at different sizes due to asymmetry between two opposing forces: (1) External economies associated with the group of companies located in the city center; and (2) diseconomies generated by firms' need to move to the center of a larger or smaller city. Thus, each city generally has a well-defined size, which depends on the type of firms that it accommodates. As cities vary in their industrial structural organization, they have different sizes because industries differ in respect to the external economies they can produce.

As such, whenever factors of production, in certain places, acquire productivity gains in relation to a decrease in unit production costs (i.e., increasing returns to scale), production prices of goods decrease in such a way that expands the scope of the market power of those activities in areas hitherto unexplored. Through this process, productivity gains more than offset the adverse effects of transport costs on the flow of goods, expanding the reach of local markets at the same levels of prices initially set (Lösch, 1941[1954]). The expansions of localized markets allow firms to extract internal and external economies of scale and, through a cumulative process (Myrdal, 1957), promote the growth of spatial clusters, generating and intensifying a heterogeneous distribution of productive resources in space.

1 Of course, Henderson did not discuss the concept of Post-Metropolis. For additional research on the evolution of the Metropolis during the $20^{\text {th }}$ Century, and subsequent considerations of it, see Soja $(2000,2013)$. 
Each of these aspects of agglomeration economies provides a possible rationale for the question of why regions characterized by agglomerations will engender greater economic growth than areas without such features.

\subsection{Centrality}

Among the various theories of urban development, one of that has had the greatest impact on both regional economics and economic geography literature is Central Place Theory (Goldstein; Moses, 1973). The most prominent authors to develop this framework were Christaller (1966 [1933]) and Lösch (1941 [1954]), although several others have also worked closely with it (Berry, 1964; Berry; Pred, 1961; Beckmann, 1968; Parr, 1997; Bennett; Graham, 1998).

Lösch (1941[1954]) and Christaller (1933[1966]) were key to developing the concept of centrality of a specific region. In Lösch (op.cit.), a spatial demand curve is determined by transportation costs as the variable affecting the territorial limits of demand, making the "market area" a key concept (Ablas, 1982). The good produced in a specific region is offered at distance-rising costs (given by transportation costs), and the spatial range of supply is given by the minimization of distance-related costs (Richardson, 1972; Holland, 1976). Spatial market areas are then hexagonally structured according to opposite forces rising from transportation costs and economies of scale (Parr, 2002a). The outcome is the uneven distribution of production and population throughout the space. The turning point in the theory is that the distribution of regional economic activities primarily evolves through few given points in space.

Christaller's (1933[1966]) model encompasses goods and services' demand functions that are also determined, as in Lösch (1941[1954]), by transportation costs and economies of scale. According to Christaller, regionally inclusive centrality functions describe the orientation of regional supply points towards local and neighboring markets. The localities work as specialized suppliers of services fulfilling specific demands of those markets. Moreover, the position in a hierarchy of central places is determined by the degree of local specialization in offering goods and services, or more specifically, by the maximum spatial range such special products are capable of reaching. The rank of a good or service (or the place's function) 
increases according to the sophistication of the goods and/or the size of their market area (Figueiredo, 2009). It is exactly this hierarchy of services that mostly distinguishes the work of Christaller (1933[1966]) from Lösch (1941[1954]). The regional distribution of economic activities follows a hierarchical system, from low order places with very few sophisticated services to high order central places, their interconnections and diversified range of services. It is important to note that the central place definition surpasses the geographical nexus. In the words of Christaller,

A place deserves the designation center only when it actually performs the function
of a center. It performs this function if the inhabitants have professions which are
bound by necessity to a central location. These professions will be called central
professions. The goods being produced at the central place, just because it is cen-
tral, and the services offered at the central place, will be called central goods and
central services. Similarly, we shall speak of dispersed goods and dispersed servi-
ces in reference to goods which are produced or offered at dispersed places and of
indifferent goods and indifferent services in reference to goods which are not neces-
sarily produced or offered centrally or dispersedly (Christaller, 1933[1966], p. 19)

It is evident from the above definitions that the concept of central place is not absolute, but relative both to the complementary area as well as to the other central places. In the words of Christaller,

Those places which have central functions that extend over a larger region, in which other central places of less importance exist, are called central places of a higher order. Those which have only local central importance for the immediate vicinity are called, correspondingly, central places of a lower and of the lowest order. Smaller places which usually have no central importance and which exercise fewer central functions are called auxiliary central places. (Christaller, 1933[1966], p. 17)

The Christallerian model is not free from criticisms. According to Cuadrado-Roura (2013), improvements in transport costs may modify any regular distribution of activities and corridors of towns may be created on axes of development. Moreover, the model has other limitations, such as a very simple argument for consumer behavior and a low explanation power for the location of service industries.

Nonetheless, the history of central places is not about inertia: new centralities emerge over time-space prisms while some decay. This perception can be framed through so-called competition among cities (Rolnik, 2015) or on smaller scales within the same city or metropolitan region or city-region. In this latter case, a plethora of authors has recognized the extension of what was restricted to the inner city to increasingly diversified, complex and polycentric suburbs. As Soja (2000) noted, maybe the suburban now has become urban. 
Table 1 Expressions used to describe Contemporary Cities

\begin{tabular}{lr}
\hline Taxonomies & Authors \\
\hline Outer City & Muller (1976) \\
\hline Edge City & Garreau (1991) \\
\hline Global City & Sassen (1991) \\
\hline 100 Mile City & Sudjic (1992) \\
\hline Metapolis & Ascher (1995) \\
\hline Generic City & Koolhaas (1995) \\
\hline Mega-cities/Metropolitan Galaxies & Castells (1996) \\
\hline City Lite & Bender (1996) \\
\hline Exopolis & Soja (2000) \\
\hline Limitless City & Gillham (2002) \\
\hline Edgeless City & Lang (2003) \\
\hline Tecnurbia & Fishman (2004) \\
\hline Neoliberal City & Parr (2005) \\
\hline City-Region & Brenner and Theodore (2002) \\
\hline Exurbia & Kruegmann (2005) \\
\hline Aerotropolis & Kasarda (2006) \\
\hline S
\end{tabular}

Source: Our own compilation from authors' works.

Worldwide, during the Fordist-Keynesian era, industrialization created a huge dispersion of population around urban peripheries. In the United States, this process was accompanied by the so-called white flight, the internal migration of primarily wealthy white populations to new suburbs, resulting in the decay of inner cities. Since the 1960s, dispersed neighborhoods have experienced growth within the services sector, such as giant shopping malls and hotels, and the materialization of the new techno-economic paradigm: technopolis. Furthermore, the expansion of gated communities around the world, related with the marketing discourse of an "urban utopia to a middle-class population battered by economic restructuring, fearful of crime, and hungry for the new and better images of post metropolitan life" (Soja, 2000, p. 250), also intensified this process. The intensification of globalization and subsequent expansion of new international airports has also fostered the dispersion process due to the peripherally located nature of this infrastructure, leading to the marketing discourse of "Aerotropolis" (Almeida, 2015; Harvey, 2014; Kasarda; Lindsey, 2011). Table 1 displays terms used within the academic literature 
that have been used to describe processes of suburbanization, sprawl, and emergence of new centralities.

\section{Financial aspects of regional and urban growth}

The objective of this section is to discuss the theoretical local growth and financial attributes from a perspective that assumes their intrinsic urban features. Financial services fall into the larger category of services or tertiary activities, which are characterized by their diversity. The heterogeneity of the service industry implies that the location of firms offering services is also characterized by a high diversity, creating difficulties in determining patterns and dynamics of location of providers of these activities.

Nonetheless, some contributions to the topic indicate factors driving intra-urban localization and growth of financial services. In the sections above we have explored several arguments, giving more importance to agglomeration and centrality features in urban growth literature. In this section we will first briefly address the main literature on the intra-urban location and growth of services, and then concentrate on the characteristics of the distribution of financial services.

By considering specific regional and urban characteristics of financial processes and markets, this section moves towards a new comprehension of growth, one that is urban-oriented, to describe the connections between urban spatial structure and financial services. This theoretical approach includes the interrelations between the evolution of an urban hierarchical network of financial institutions and the services they provide, incorporating the effects of localized internal and external economies, and also excavating the macroeconomic layers of economic geography. To clarify these points, we highlight the concept of financial agglomeration in order to explain the deepening of urban finance and funding processes, mostly in terms of economies of localization, of urbanization and of complex activities. Moreover, the concept of centrality is also envisaged, since it is crucial to explain the urban hierarchy of financial services (central goods) and the urban character of the distribution of such goods. The possibility of multi-centered spaces of (diverse) centrality in the urban context arises as the outcome of such distribution, which is related to other urban 
drivers such as agglomeration of diverse economic activity, job centers, inter-urban mobility, and land value.

\subsection{Intra-urban location of services}

As mentioned above, studies on the location of services have usually been built on conventional theories of location of productive activities, such as theories of market areas and central places and those related to the location of firms within cities. However, these contributions have been quite insufficient, since the diversity of services makes it difficult to generalize on the subject. Moreover, the lack of empirical studies add extra difficulties to the analysis of the theme (Cuadrado-Roura, 2013). As a result, new approaches to the location of services are less concerned with establishing generalizable rules and more focused on developing research into a more detailed, disaggregated level.

An essential part of urban economics and geography is concerned with the elements that can elucidate how cities are organized internally and how land is occupied. From this perspective, one can stress that the location of services (at different levels and degrees) should be included as an important factor for the changing structure of metropolitan areas and the evolution of their centers and sub-centers (Cuadrado-Roura, op. cit.).

One of the main contributions to the comprehension of intra-urban features is the idea of monocentric city and Central Business Districts (CBD). City centers have traditionally concentrated a large share of services, from small business to specialized services, including public ones (religious, administrative, and cultural). This holds true for many cities, despite significant contemporaneous changes in larger cities, such as suburbanization mentioned above. Also, there is a quite significant effort to revitalize city centers which had experienced a long period of deterioration and neglect by public authorities.

The idea of downtown and city center has usually been associated with the concept of CBD in the present (Derycke, 1992; Glaeser; Gottlieb, 2009), occupied by financial services, professional offices (lawyers, consultants, etc.) and their specialized activities (media and advertising) and corporate headquarters, along with other cultural and leisure activities. 
Land rent theories can also significantly contribute to the comprehension of urban features of services' location. In Von Thunen (1826[1875]), some principles of accessibility and spatial competition were initially suggested in order to explain the use of land and civil construction in a city. In a posterior study, Alonso (1964) suggested the inclusion of rent curves with differentiation given by the distance between a portion of land and the city center. Many different service providers (such as banking and financial services) may deal with higher supply costs than small industries, which may explain patterns of city center and certain business areas concentration of such activities, since these services providers are able to face higher costs. Moreover, the model helps to explain the dynamics of centralities and the emergence of new polarizing and polarized places. Still under such arguments, Lowry's (1964) model may also contribute to the comprehension of the changing dynamics of services. The latter model, which puts variables related to economic base, population and employment in services together by means of their spatial interaction, makes it possible to study the propensity of near population jobs and services to agglomerate.

Over the last forty years, cities have undergone several changes. These changes are related to centrifugal forces relocating productive activities and population. Services have also been relocating, following the move of industries to peripheries, although more sluggishly, often to the urban fringes. Administration and business management, human resources, political and public administrative services, hotel facilities etc. have moved to places that are not far away from city centers. Additionally, an increasing trend can be viewed in the relocation of urban leisure facilities (movie theaters, restaurants, pubs, and indoor sports grounds) to new city centers and sub-centers (Cuadrado-Roura, 2013, p. 262). Underlying this process is the cost of land and scarcity of developable land, congestion costs, degradation of central areas, and municipal policies and regulations favoring relocations, which are ultimately encouraged by transportation infrastructure. The result is that cities are becoming increasingly dispersed and polycentric, incorporating new centers where land value increases together with location advantages, nature of buildings and quality of infrastructure. Real estate market prices reveal the private capital preferences of space and the potential opportunities offered by new areas. It changes restrictions, affecting the evolution of urban nodes (Abramo, 2007; Almeida 2015). 
Financial services, as part of the services industry, have their own particular location and growth dynamics. Given its high agglomeration and centralization tendencies, financial services are inherently related to urban growth, especially to the development of urban nodes or local sub-centralities. The next section explores the logic of urban agglomeration and centralization, with emphasis on the dynamics of financial services.

\subsection{Economic and urban restructuring: financial domination of the space}

Although banks have been relevant at least since the end of the Middle Ages, only in the last four decades the financial sector took the dominance of the accumulation regime. In other words, the financial sector became the primary actor in the appropriation of the national surplus, as many authors have argued (Almeida, 2016; Betancur, 2014; Brenner; Theodore, 2002; Fix, 2007; Harvey, 2014; Palma, 2009; Rolnik, 2013). This new era of financial predominance comes as a substitute for the previous era when industrial production was the dynamic center of the accumulation process. Figures 1 and 2 depict this change for the case of USA's economy. As Betancur $(2014$, p. 2) notes, "this shift occurred principally in the North in the decade of the 1970s, consolidating in the 1980s, and migrating elsewhere through the actions and influences of the North on tributary economies".

This shift of regimes had a strong spatial implication. Economic restructuring led to urban restructuring. According to Betancur (2014),

\footnotetext{
Spatial practice in its entirety includes reorganization of the industry of space around finance, insurance, and real estate (FIRE); as the financial industry became dominant amassing the largest exchange value ever, space became one of its main tools while securitization sped up circulation, deregulation made room for highly speculative financial instruments, and the state brought all forces together around a new developmentalist agenda and form (governance). (Betancur, 2014, p. 2).
}

Drawing on Henri Lefebvre (1991[1974]) argument that each accumulation generates its own space ("production of space"), once industrialization shaped metropolises and megacities around the world, this era of financialization and globalization has been shaping the so-called "neoliberal city" or "global city". Far from discussing in details the meaning of each of these expressions, we shall highlight the continuous tendency of privati- 
Figure 1 Manufacturing participation on GDP - USA (1947 - 2004)

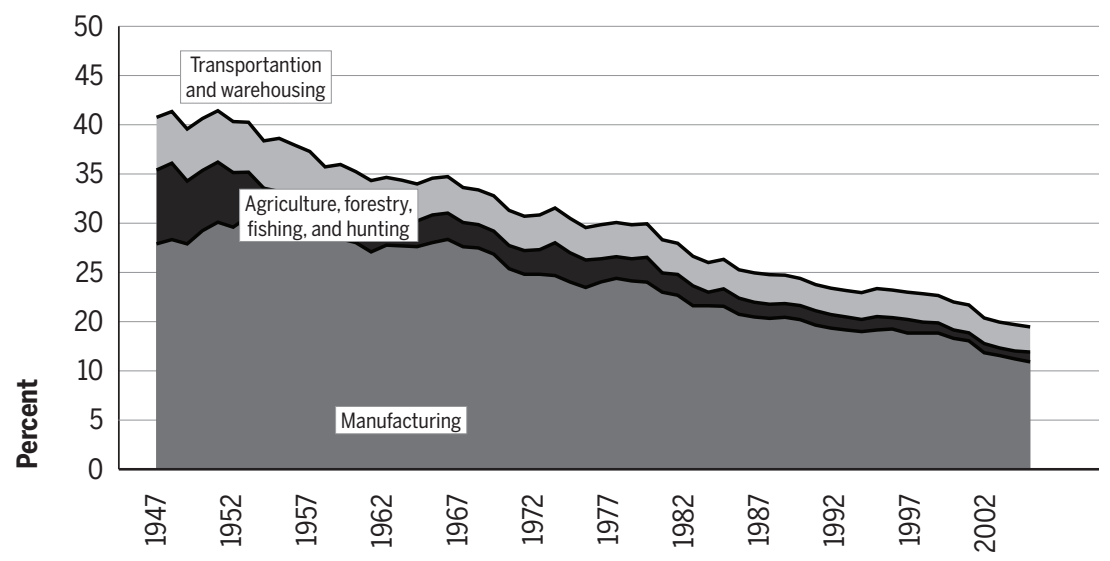

Source: (Leamer, 2007).

Figure 2 FIRE participation on GDP - USA (1947 - 2004)

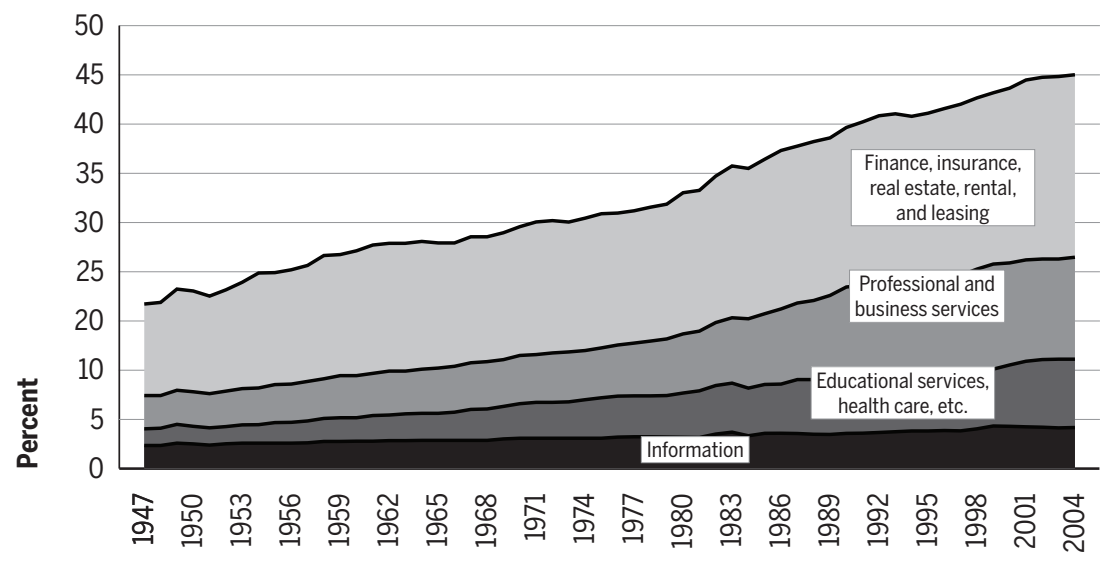

Source: Leamer (2007).

zation of cities' space and public services; the penetration of global liquidity circuits through almost any economic activity within the urban space; the agglomeration of financial services in fancy districts; the emergence of multinational companies' headquarters in cities' central areas; and the real estate market boom in the last decade - that led to the global crisis in 2008. In the adaptation to the new regime, large-scale urban projects have been key instruments to change cities' structures in face of the new domination 
(Cuenya, 2011). These backbones, expressions of the financial industry over the cities, have been increasing in size and frequency in such a manner that Flyvbjerg (2014) called our times of the "megaproject era". From another perspective, a number of authors have been using the expression the "megabanking era" (Dymski; Kaltenbrunner, 2014).

It is hard to deny the spatial restructuring that financial industry has been operating in a global scale. From Singapore to Bahamas, from Johannesburg to Frankfurt, from Amazon to Chicago, from Tokyo to New York, financial firms' headquarters, stock exchange buildings, commodities markets and Multi-national Companies (MNC) have been reshaping urban space. Perhaps these changes are less clear in poor areas from the Global South, although they are also there. Personal debt, credit cards, insurance and banks posts are also there. Before we can further analyze the financial dynamics in an urban context, it is necessary to discuss the features characterizing the locational dynamics of financial institutions. The next sections explore the rationale behind financial institutions locational decisions.

\subsection{Financial services agglomeration}

In a nutshell, spatial concentration is a process that enables firms to reduce costs by using regionally oriented internal, and external economies. The same idea can be extended to financial activities, since the interaction between internal and external local factors is still valid for financial markets (Thrift, 1994). A basic feature of financial markets is that they need to be intrinsically large, as the necessity to be constantly liquid requires them to grow sufficiently enough to allow investors and users in general to enter and leave at will. This also explains why financial markets are usually locally concentrated and unequally spread over the territory, as the conditions to grow are not found everywhere.

The dimensional characteristics of financial markets make them more likely to be formed by hierarchical social micro-networks (intrinsically urban) of buyers and sellers, with important effects on price setting by the financial institutions. The dissemination of information in these markets, and the related volatility brought by it, makes it crucial to form a social network to track and process all the necessary information in order to generate interpretative schemes of information. The financial urban place is, thus, the locus 
of concentration of such flows of information, which can ultimately lead to an uneven spread of interpretations and information through a wider regional network. From a Post-Keynesian view, we might say that the financial urban concentration is the locus where conventions - psychological set of common beliefs that guide behaviors in from uncertainty - are shared in the financial markets (Carvalho, 2014). The regional space becomes a fragmented set of financial sub-spaces (urban localities) with different settings of information and interpretation, turning spatial concentration into a natural response to diversely disseminated pieces of information.

In urban terms, specialized human resources and better developed infrastructure promote financial concentration through the improvements in costs related to transactions and information. Financial firms benefit from localization features derived from the magnitude of the local economic activity, which is also responsible for further clustering of other financial activities. This is valid for all types of financial institutions and the services they offer. According to Parr and Budd (2000), from the point of view of the local size of financial markets, broad local markets improve liquidity and the share of risks, which in turn allow financial institutions to operate with lower spreads on their services. Alternatively, price signals in shallow markets (usually along the peripheries) fluctuate rather discontinuously, which imposes limits on trading activities. In terms of simple financial intermediation, local markets can be differentiated by the possibilities of transforming risk, maturity of assets (liquidity), and transaction costs. Thus, the efficient management of local portfolios has a significant impact on the valuation of financial assets.

The dynamics of size effects in the markets and the interrelations between businesses and financial firms are also important factors for the spatial settlement of financial relations. The more firms there are, the greater the fixed cost of operating in financial markets can be shared (e.g. settlement, payment, and document transportation systems). Thus, financial firms derive significant benefits from being localized in specific places. Localization economies enable the attraction of more contacts, information turnover, greater liquidity and expertise that can foster financial innovation. Moreover, financial concentration enables further aggregation of not only a pool of specialized labor, but also of ancillary services such as accounting, legal, and computer programming, which further reduces overall costs of these services. 
According to Cavalcante (2012), the concentration of financial activity occurs whenever the local demand and better general expectations prompt an increased offer of financial services at lower costs for financial firms and individuals. In these terms, financial concentration is demand-driven and supply-limited ${ }^{2}$. Thus, given a specific local income, financial concentration can be considered to be driven by the replication of local financial services at falling costs for financial firms in a specific region. The improvement in prospects for the region are accompanied by local economies of scale that reduce the average cost of financial service provision, while external economies such as the ones related to urban and complex economies provide further cost reductions by means of better organizational, informational and structural conditions in the region.

Once agglomeration, in the sense of increased financial activity in the local market, is treated as a factor being molded by the urban context, we can start setting a theoretical background from which we can explore the urban conditioning of the financial dimensions of cities' (economic) growth. However, before doing so, another important factor must be taken into consideration. The development of local financial markets also hinges on the diversification of institutions and on the complex financial services they offer. This is because the urban features shaping the complexity of services determine the strength of spatial financial ties that eventually shape the size and limits of the city and, moreover, its position in a broader regional financial network. Hence, it is crucial to stress the idea that centralization also affects financial processes over space. This is the subject of the next section.

\subsection{Financial services centrality}

Financial markets are easily analyzed through Christaller's framework (Parr; Budd, 2000; Crocco et al., 2005, 2010). Local (regional) financial cen-

2 Two caveats are in order. First, it should be noted that technological and communication improvements enable the offer of financial activities by supraregional network, with services being offered remotely from different locations. However, demand for those services is usually connected to the local socioeconomic context. Secondly, it should also be noted that regional concentration of financial services is ultimately related to the degree of uncertainty and liquidity, features which are also intimately related to the local context. To a further discussion, see Cavalcante (2012). 
tralization may, thus, be defined as the number of complex financial services being offered at a place according to a specific hierarchy. High-order central financial places can offer a wider range of services than lower ranked places and thereby are capable of reaching more distant markets. The existence of different types of financial services with different specialization degrees is deemed to be unequally spread over the territory. Spatial differentiation in the set of financial services offered causes relative diversification in the regional costs for these financial services (Thrift, 1994).

The dynamics of centrality of a financial service is determined, following Christaller (1933[1966]), by changes in regional income. This is because producers of specialized services (e.g. financial firms) increase the spatial limits of supply whenever they sense the expansion of services can maximize profits. In terms of internal costs to financial firms, a change in centrality is related to economies of scope. As such, the diversification of financial services supplied by financial firms follows internal and external economies of urbanization and complexity. The agglomeration of financial activities provides improved managerial oversight and superior levels of coordination (Parr, 2002b) for financial firms. It also enables the latter to diversify their services and enhance the participation in the regional economy. High-order financial places are thus able to act, by virtue of its own position on the services' knowledge structure, as the main generator and propagator of product innovation (Thrift, 1994; Friedmann, 1972). This means that the high-order financial place is able to supply complex services, which are, in turn, in constant evolution following innovations in their format and content. The increased flows of income and profits that are centralized in some places not only allow reductions in costs for financial firms due to scale benefits, but also permit the diversification of products to better respond to different types of demand (liquidity and returns) by customers.

Hence, this work takes the idea of a regional financial network as functioning through financial places of different hierarchical orders, ranging from a few places with highly specialized services to low order places offering more basic services. The regional network is thus formed by the cities and the financial services they contain. Therefore, the availability of diverse complex (from low to high order) services are intrinsically an urban phenomenon, given that such availability is dependent on the local structure of economic activities, the local income generated, 
the dispersion of population and income through space, and the interrelationships between financial firms. All these factors take form through historical developments (path dependence), creating diverse types of urban financial fabrics, through virtuous and vicious cycles of development, forming a wider financial network of cities with diversely developed local financial systems.

Once the regional centrality starts to evolve in financial agglomerations, the financial hierarchy changes dynamically with variations in the connections of economic real activities and financial decisional locus between high and low order places. This is a process that promotes layered changes in space, first by affecting the urban dimension and then expanding to a wider set that encapsulates the dynamics between regions. Over time, a growing region is faced with changes in financial centralization and income that establish a new level of local financial deepening. More central services are demanded locally and the region further improves its urban growth prospects. Depending on the relation among different regions and its urban spaces, local flows of funds stimulate the offer of specialized services in different places throughout the country, creating new centralities, strengthening the finance-growth nexus in local economies and consequently promoting regional financial development.

\subsection{Urban financial dynamics}

What are then the main drivers of the urban financial dynamics? It is fundamental to understand the contribution of financial services for the inner development of the city, especially if one wants to be informed about the development of new centralities that might shape a more balanced urban landscape and help foster better urban planning.

For the development of the argument, we must address the object of study from a two-sided perspective: on the one hand, financial urban dynamics is driven by demand factors, such as income, population density, and ease of access (primarily transport costs). On the other hand, characteristics of supply of services must also be taken into account, more specifically the decision over which services to offer, and to whom they should be offered, which ultimately leads to decisions over the localization of financial services providers. The interaction between demand 
and supply factors affects dynamic growth in diverse spaces in the city, thereby altering the shapes of these places and contributing to the development of the city.

On the demand side, it is necessary to relate population size and total income as the main drivers of demand for financial services. In the literature, the usual factors underpinned as determinants of such demand are changes in population size and the purchasing power of diverse economic groups, especially the ones in which financial services represent a larger share in their total spending. Moreover, in tandem with such demands for financial services, its supply may also alter the urban hierarchy of central places (Cuadrado-Roura, 2013, p. 263). Higher levels of income are positively correlated with greater demand for financial services of diverse hierarchical order, from low to high complexity, both in terms of quantity and variety, as increasing levels of consumption and investment require financial access to a greater extent of services in order to cope with them. Financial services are, indeed, built to extract shares of income from households and firms, thus the higher the income the more eager financial service providers are to offer services that allow them to be profitable. Moreover, the higher the income, the greater the demand is for more complex services, which are also thoroughly designed to extract greater income margins.

During the last 30 years a deeper process of financialization has emerged worldwide, whereby the share of productive activities in income have lost significance to financial ones (Arrighi, 2004; Duménil; Levy, 2001). In this process Financialization also contains a very defined social dimension, where average daily life becomes increasingly dependent on financial services (Langley, 2007; Prike; Gay, 2007). According to Crocco et al. (2014) a spatial financialization process can be assumed as the spread and deepening of finance motives in the spatially conditioned actions and behavior of agents. As such, financialization becomes a spatially bounded process. The spur in financialization, as a constant rupture of common social relations embedded in regions into more intricate financial relations, can be originally limited by the degree of spatial diffusion of each specific financial relation. As long as financial services can be categorically separated by their complexity and territorial range, one could also infer that financialization will have a spatial component driving its diffusion over the territory. The regional process of financialization is, therefore, far from homogeneous. 
From the encompassing concept assumed above, one can derive specific notions for the comprehension of financialization in an urban scale. Most works on urban and economic geography analyze financialization from the point of view of changes in corporate governance of real estate companies and their effects over the space, as in Harvey (2010) and Rolnik (2013). This is a very important and useful notion, especially after the 2007-8 subprime crisis. However, our contention is that financialization must be considered a more encompassing phenomenon, spatial by nature. From this point of view, we can suggest that the formation of new urban centralities, here represented by financial services (one of the most representative elements of central services group), is increasingly driven by a financialized spatial structure of demand for and supply of financial services and the changes they provoke in social and economic behavior, which utmost affect the development of cities and metropolis.

Such a process is far from being a balanced one. In a world were technological transition has accelerated in diverse areas, the structural organizational of firms, coupled with new ICT technologies, have indeed penetrated the financial services industry, spreading activities in different degrees according to population demands, even entering areas that were considered of lesser significance (Cuadrado-Roura, 2013), enabling financial services providers to reach newer and larger market areas and population, including low income social groups. These individuals usually lack access to financial services and are thus financially excluded, having to cope with heavy burdens restricting their access to other types of services and goods. Financial exclusion may turn into financial exploration once income improves for the poorer, since the latter may not have the financial literacy to understand and make decisions over the consumption of financial services. Financial services may then spread to peripheries through a process that allows the evolution of new sub-centralities and deconcentration, although this process may be tempered with the misuse of financial services, which may lead to over-indebtedness and unfair financial relations.

It should also be mentioned that such intra-urban financial features operate through a very defined regional and global hierarchical network. The relationships of cities with their catchment areas have changed greatly as a result of new transportation and connection systems. The major changes in city networks and systems have been eliminating lower-level centers and strengthening major poles and national centers, allowing the emer- 
gence of a limited number of global cities (Sassen, 1991) which ultimately centralize decisions that impact the whole system. Highly complex financial services will be necessarily located at major city centers, as they also rely on complex information and face-to-face contacts. However, the need to extract higher shares of income will eventually drive financial services to be located in new areas, where prospects of population and income are positive. This is especially true if these new areas contain some kind of productive activity, which may also require jobs of diverse complexity (high and low skilled).

In recent decades, with the increase in communication and information technologies, a debate has risen over the end of the necessity of a physical presence for banks and other financial providers. This should not be taken as granted. It is true that remote services are gaining more significance in daily financial operations, especially for low complexity services. However, these services are not widespread throughout the population, especially in countries with high rates of income inequality, where large shares of the population are completely financially excluded or have great difficulties in accessing financial services. Moreover, there are very complex services, which will continue to require face-to-face contacts, requiring specialized labor to conduct such transactions. This is in tandem with the need to deal with highly complex (hard) information in order to manage some financial services. From an urban perspective, many low-income areas lack access to nearby services and remote financial services. Yet in these cases, there is still a logic to the physical presence of financial providers, as face-to-face contacts are still preferred, even for low complex financial services.

While demand factors for finance are key to the urban dynamics, the supply of financial services should not be dismissed. Decisions over the quantity and complexity of services that should be provided are fundamentally driven by demand, but they are also carefully designed to maximize returns for financial service providers. Therefore, decisions on where to locate and which services to provide at what price are deeply rooted in space, and land value and urban amenities likely play a role in such decisions. There is, indeed, a historical urban development process that is characterized by a path dependence that shapes the localization of financial providers. Once they decide where to locate, agglomeration economies take place and financial spatial concentration begins. However, the dyna- 
mics of urban development usually opens new spaces in the city, allowing new opportunities for financial services expansion. It is also likely that the supply of more complex financial services is also correlated with the development of specific centralities in the city. In this process, land value might appear to be a significant feature shaping the decisions over the localization of banks and other financial providers.

Financial services are unique in that they are able to recreate and foster economic activity. Financial services providers, such as banks, have the means to offer services that not only reduce costs but also foster other economic activities. This is the case of the provision of loans by the bank system. Once located in a new area, banks are capable of advancing loans to individuals and firms that may, when investments are local, support urban development. Therefore, financial activity will not only follow, but also create its own demand. From an urban perspective, this means that financial services can anticipate the formation of new centralities and, thus, foster such development.

\section{Empirical analysis}

This section highlights localization patterns of brick-and-mortar financial service providers through empirical analyses from within the Metropolitan Region of Belo Horizonte (MRBH). The analysis is carried with available data spanning from 2000 to 2015 in different periods: information on income and population is from the Census (IBGE, 2000; 2010), while data on banks' branches and posts are from 2007 and 2015. Despite being available in different periods, data cover a fifteen-year span when it is fair to assume the Brazilian economy has prospered (income growth and falling inequalities). A preliminary investigation, thus, is conducted by analyzing the correlation between financial services and some key variables for the metropolitan region. $\mathrm{MRBH}$ is the third most populous in Brazil, with more than 5 million residents, being a part of the sample selected by United Nations-Habitat to include the global Atlas of Urban Expansion ${ }^{3}$, as a fast growing urban center in the world. Differently from other major metropolises in Brazil, such as São Paulo, Rio de Janeiro, Salvador and Porto Alegre, 3 To check a number of variables for Belo Horizonte, see: http://www.atlasofurbanexpansion.org/cities/view/Belo_Horizonte 
Belo Horizonte was a planned city, built in the end of the $19^{\text {th }}$ Century to be the state capital. As a typical Latin American metropolis, Belo Horizonte undergone an intense process of urbanization and industrialization in the $20^{\text {th }}$ Century, with a remarkable social inequality and socio-spatial segregation. Its spatial structure and economy reflects a combination of industrial districts, centers of advanced services, high buildings and gated suburban communities, slums, car-dependent transportation and a very significant informal sector.

Figure 3 Metropolitan Region of Belo Horizonte (MRBH)

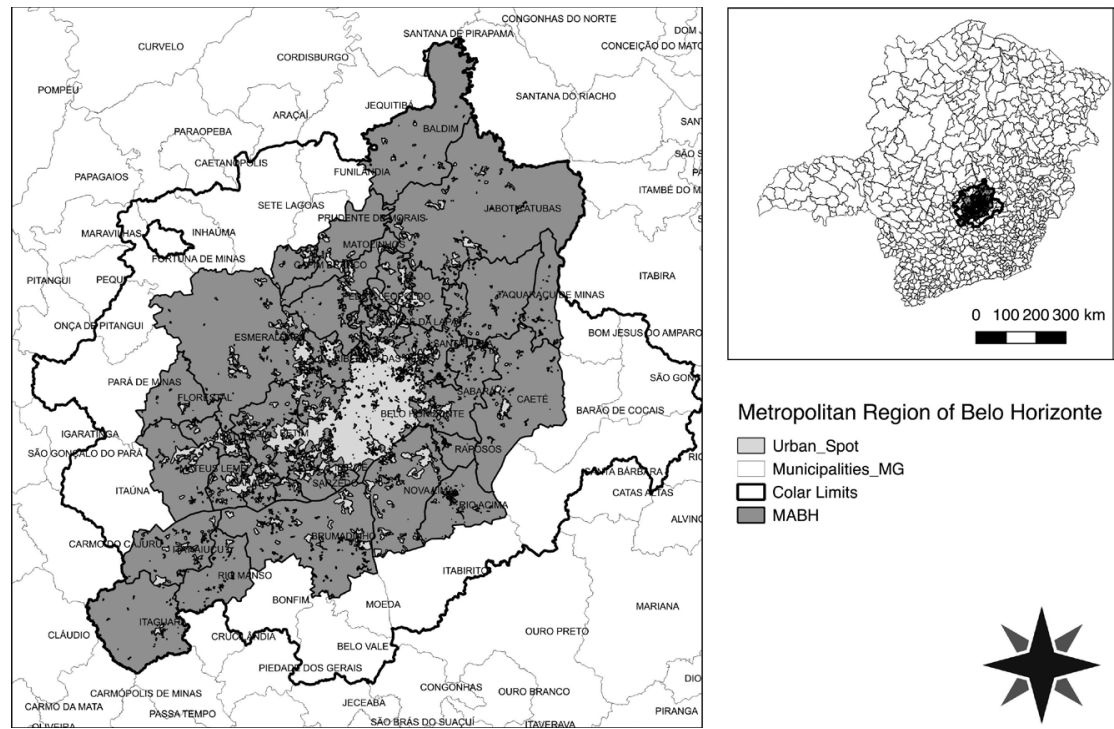

Source: UFMG (2014).

Belo Horizonte, the capital city of Minas Gerais State, Brazilian second most populous State, has a high concentration of public institutions and a significant part of the job distribution is composed by public servants. Moreover, the city is a place of several companies' headquarters, from sectors such as public utilities, steel, mining, information and technology (IT), construction, logistics, health care, banking, and agribusiness. Figure 3 shows the administrative regions of $\mathrm{MRBH}$.

Next, the financial services dynamics is analyzed through the localization pattern of bank posts and branches. There are very significant differences between the two objects of study. A bank branch requires 
a bigger physical structure and a more diversified labor force. The bank branch is able to offer a wider range of banking services, from very simple to very complex services. Bank posts, on the other hand, are places where more simple banking services are offered, from automated teller machines to mail and lottery offices. These providers are directly subordinated to banks, serving as outposts supplying low complexity services (cash withdrawal, payments of bills, etc.). We thus have a hierarchical difference between a bank branch and a post. The former is able to replicate its services activities to a larger area, while posts usually serve the immediate vicinities.

Income and population data come from IBGE census, while the Central Bank of Brazil provides information on banks and posts localization. Data on land values and real estate was compiled from the local city hall. Table 2 offers some figures on banks and posts among the 7776 boroughs in the Metropolitan Region of Belo Horizonte (MRBH).

Table 2 Banks branches and posts by borough in the MRBH (2010)

\begin{tabular}{lr|r|r|r}
\hline & Obs. & Average & $\begin{array}{r}\text { Std } \\
\text { Deviation }\end{array}$ & Max \\
\hline Banks Branches per Borough & 273 & 0.074 & 0.569 & 18 \\
\hline Banks Posts per Borough & 620 & 0.201 & 1,292 & 64 \\
\hline Branches-Posts per Persons in Boroughs & 728 & 0.028 & 0.385 & 10 \\
\hline Branches-Posts per Income in Boroughs & 728 & 0.0026 & 0.0054 & 0.0783 \\
\hline
\end{tabular}

Source: Central Bank of Brazil (2010) and IBGE (2010); Boroughs are given by the IBGE Census Tract.

It should be noted that only 263 neighborhoods have banks' branches (3.4\% of the total) while banks' posts are present in 620 localities $(7.9 \%)$. These numbers indicate that there are 7 banks branches at every 100 boroughs (or 1 at every 13 boroughs). In the case of banks' posts, which offer less complex services, there is 1 post at every 5 boroughs. Moreover, data show that there were almost 3 banks and/or posts per 100 persons in the $\mathrm{MRBH}$ and 2.6 banks and/or posts per $\mathrm{R} \$ 1000$ of average income. This information, therefore, may indicate the high level of spatial concentration of banking services in the metropolitan area and, thus, the relevance of the Center Business District (CBD).

One first point to highlight relates to monocentricity, a cornerstone for urban economics, commonly considered in terms of population density. 
Figure 4 displays the density for all areas within the metropolitan region as well as all other areas within a 100-kilometer radius from the supposed CBD - Praça 7, in the historical center of Belo Horizonte.

\section{Figure 4 Population density Belo Horizonte Metropolitan Area}

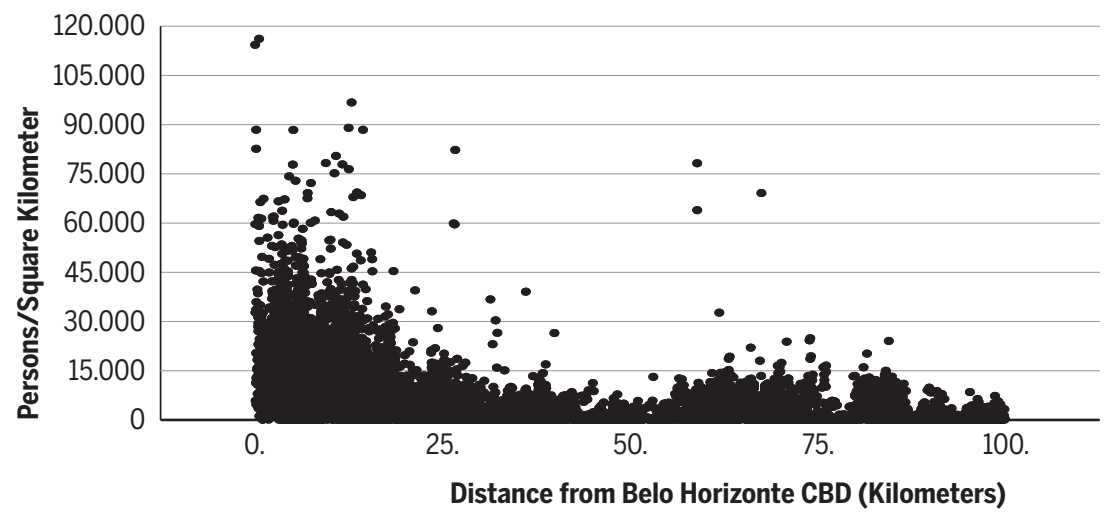

Source: Own tabulations based on Census Tracts from IBGE (2010).

Figure 4 portrays some evidences of a monocentric urban pattern, with the highest concentration of populations residing within 15 kilometers of the $\mathrm{CBD}$, the distance between Praça 7 and Contagem, the $2^{\text {nd }}$ biggest city in the metropolitan region. Several spikes in highly populated areas appear 25 kilometers and 32 kilometers from the CBD, representing polycentric population concentrations, like Betim, Ribeirão das Neves, and Vespasiano (Figure 3). There is a clear pattern of logarithmic decay in general. However, there are also indications of dispersal and polycentricity. It is also clear that after the range of $50 \mathrm{~km}$, new larger agglomerations appear, representing downtowns of cities in the metropolitan collar and along the border of the metro area. If we shed some light on what occurs "inside" the capital city (Figure 5), the hypothesis of monocentricity weakens - at least if we consider Praça 7.

Figure 5 exposes density increases in the range between 0 and $4 \mathrm{~km}$ from downtown, with a large concentration around the fourth $\mathrm{km}$. It is the 'Savassi effect': the intense concentration of very high-income people living in relatively small apartments around Savassi borough, a fancy area located south from downtown, with a strong concentration of complex services. For instance, Savassi's Human Development Index 
is higher than any country in the world ${ }^{4}$. This phenomenon leads to a high concentration of people within a very small and well-planned area - being an island of prosperity when compared with the entire metropolitan region or even the nation. Other trends also appear in Figure 5 moving from left to right in the horizontal axis. Around the fifth kilometer, the density drops, and then increases again between six and seven kilometers from the CBD. This is due to the effect of suburbanization and presence of other centralities such as the neighborhoods of Buritis to the southwest, Ouro Preto and Castelo (Pampulha region), and Cidade Nova to the Northeast (Figure 6). These are neighborhoods of high and middle-income people, where an intense process of verticalization happened in the last 15 years, correlated with the Brazilian economic growth in the time period 2003-2014.

Figure 5 Population density*, 0-16 kilometers - Belo Horizonte (2010)

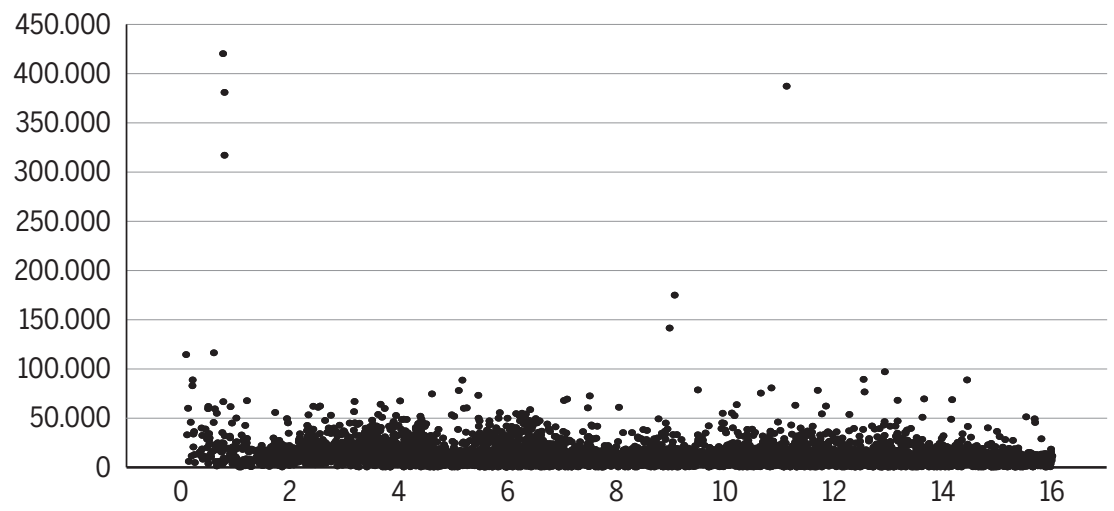

Source: Own tabulations based on Census (2010). *Census Tracts were grouped in neighborhoods.

Density subsequently decreases to the $15^{\text {th }}$ kilometer in Figure 5, with the high-density district of Venda Nova, located to the north, appearing as an outlier at around 11 kilometers from the CBD. Venda Nova is a typical popular centrality of Brazilian metropolises, a hub of mass transportation, with narrow streets full of pedestrians during the day, popular chain supermarkets and stores, and most people living in single-families houses, subject to violence and floods. 
Figure 6 Population density (2010) and featured localities in Belo Horizonte

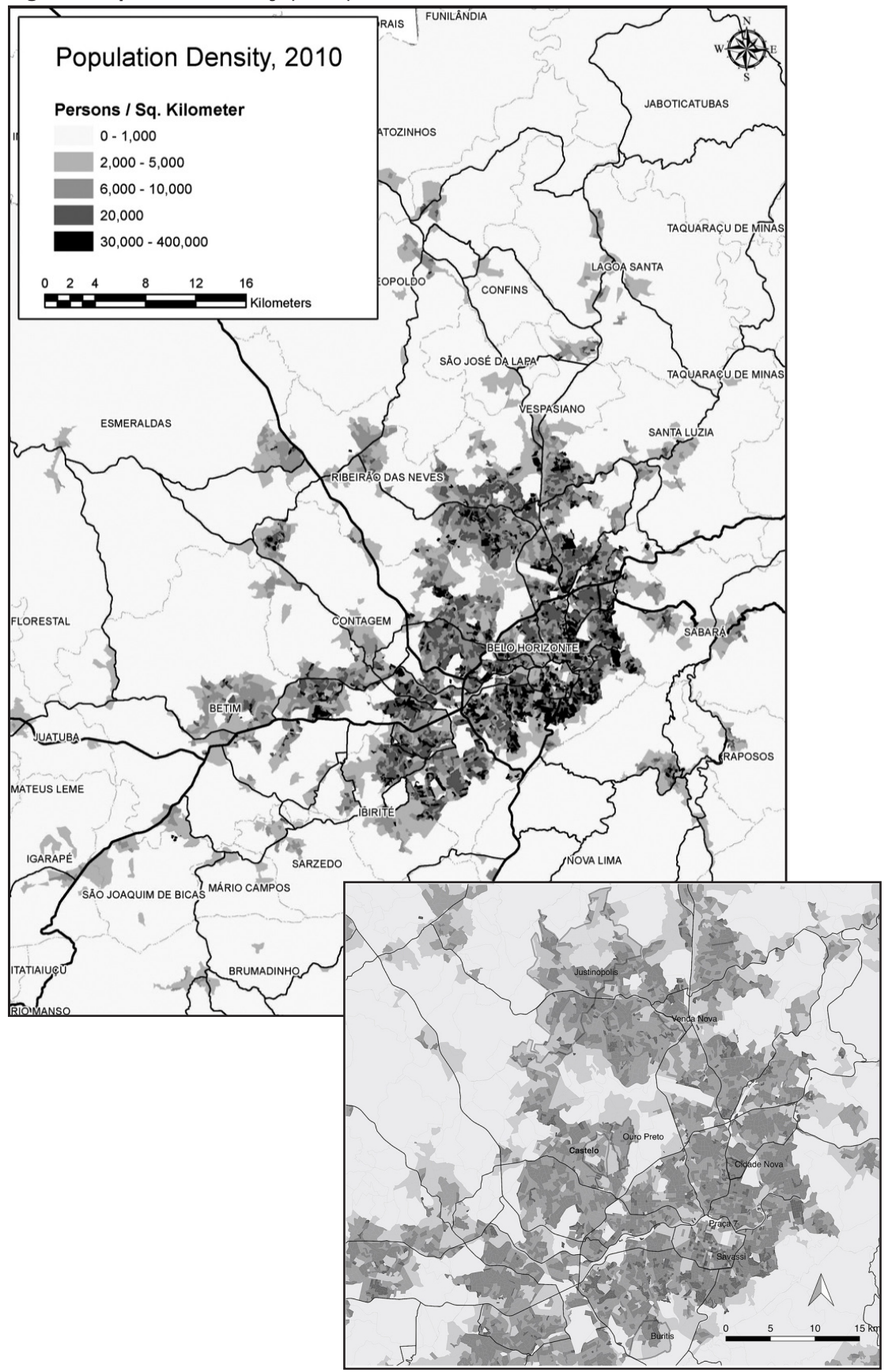

Source: Own tabulations based on Census (2010). 
Following such panorama, Figure 7 displays the number and the price of apartment transactions in 2012 within Belo Horizonte limits, and the average income of each area within the city. It is worth mentioning that some suburban centralities, like Buritis, Caste10 and Cidade Nova are relatively new creations of real estate developers. The concentration of white dots describes these suburban centralities as verticalized upper middle-classes neighborhoods. It is important to note that the primary concentration of high-income populations, within Savassi/South Zone, continues to harbor a large number of transactions of luxury apartments. Meanwhile, sales of lower priced apartments occurred especially in Pampulha region and in Venda Nova region.

Figure 7 New apartment values in Belo Horizonte, 2012

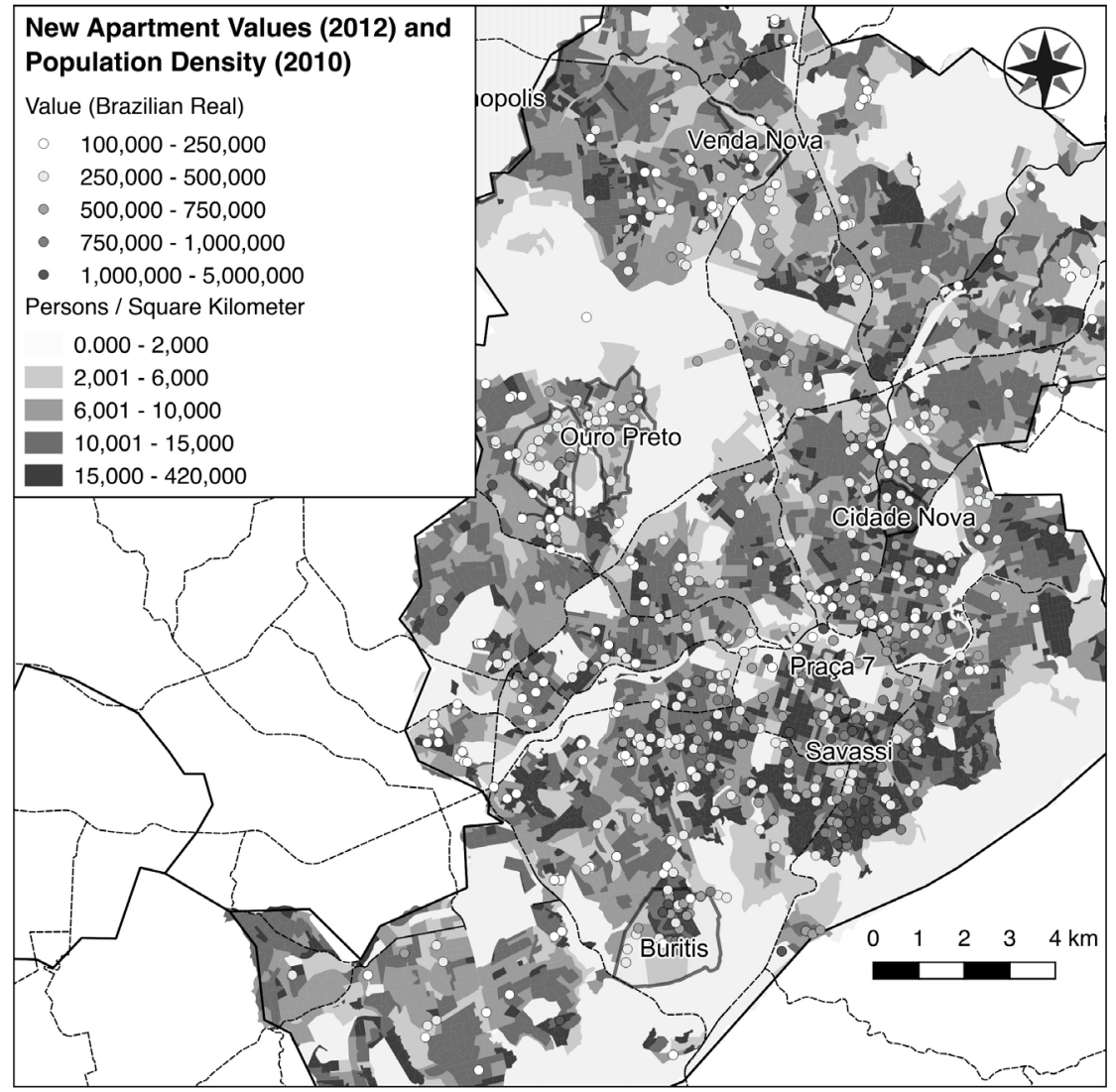

Source: Own tabulations based on Census (2010) and IPEAD data. 
What about the financial centralities, or the dispersion of financial services? One might consider that the total income of an area (i.e., the market potential) is more important to the banks' strategy than solely the concentration of people or the average income of an area. Total income represents the average income multiplied by the number of residents in a given area. Therefore, Figure 8 exposes how the South zone agglomeration represents the main 'mass' of income in the metro area, as well as some centralities such as Buritis, Ouro Preto/Castelo and Cidade Nova, which also have high income mass concentration. The North area of the city, e.g. Venda Nova, despite the large number of residents, does not have a high total income, expressing the inequality that describes Brazilian society.

\section{Figure 8 Total monthly income in the MRBH}

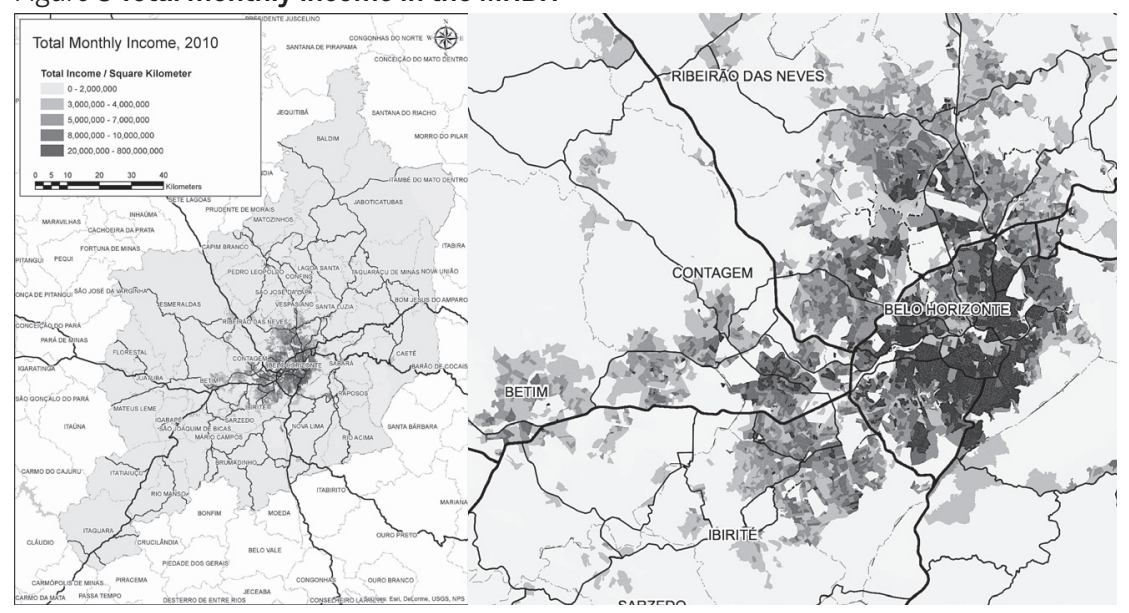

Source: IBGE (2010).

Figure 9 shows the concentration of bank branches and bank posts within the metropolitan region, while Figure 11 shows the growth direction of new banks branches from 2007 through 2015. A first look at Figure 9 will reveal a very concentrated pattern of location, highly correlated to income distribution. There is also presence of very few banking services providers in other municipalities, which indicates places of smaller centralities (Caeté, Brumadinho, Betim, and Santa Luzia). These are all given sub-centralities in the metropolitan region. Nonetheless, a closer look at the location of new branches and posts reveals the dynamics of the hypercentrality (downtown Belo Horizonte) and its subcentralities. 
Figure 9 Income, banks branches and posts, downtown Belo Horizonte, 2015

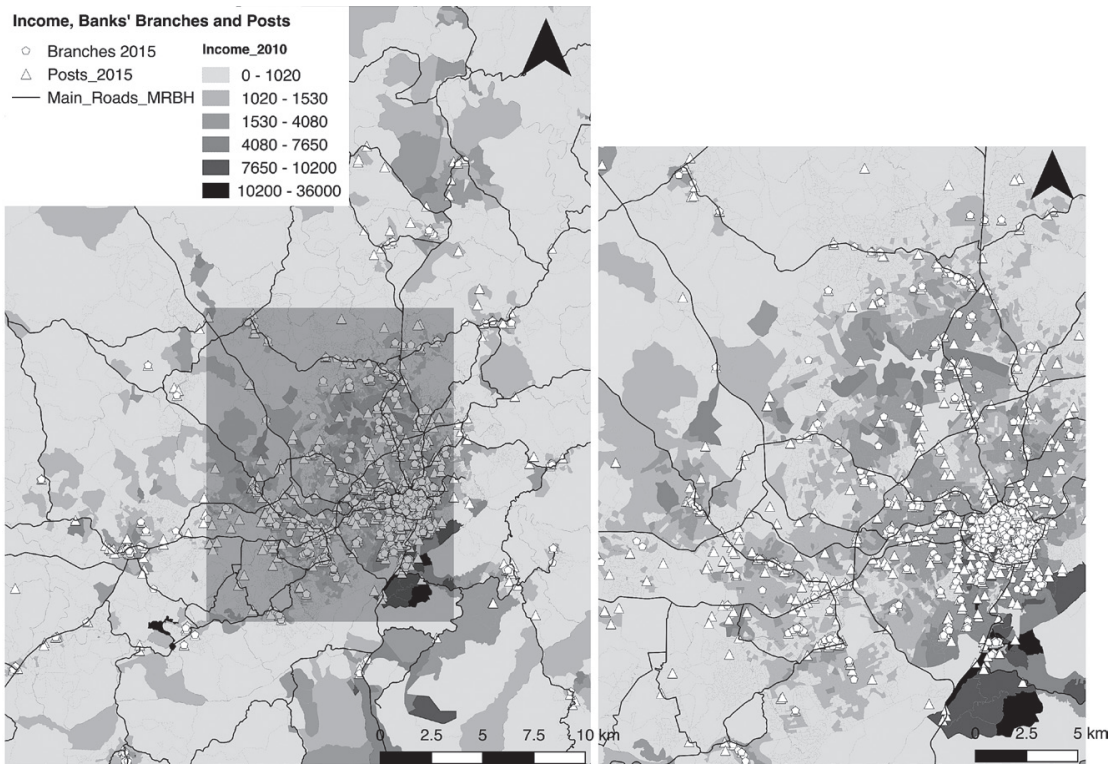

Source: IBGE (2010), Central Bank of Brazil (2015).

Given this preliminary analysis, it is possible to infer that there are some significant trends in the metropolitan region. First, one must refer to the downtown area. Historically, banks were initially located at Belo Horizonte city center (represented by Praça Sete). Over time, new bank branches have moved to the south of the city center, following the increases in population and income mass in the area, which are very high in the southern neighborhoods (Figure 10). However, banks have maintained their original historical location as most of the movement in banks branches and posts are towards the north and west from the CBD (Praça 7/Savassi). We can then assume that some path dependence is significant in banking services location. This is probably due to the very hierarchical nature of the services, running from bank headquarters (also nationally) to branches of a lesser order to posts.

Figure 11 displays an urban development vector to the west, in the direction of Contagem and Betim, which are municipalities that have been marked by strong economic activitiy - huge industrial plants. New bank branches and posts have been located along the main centralities within the municipalities. Therefore, centripetal forces stemming from agglomeration of activities may be taken as the main drivers of such centralities. 
Moreover, land rents are also relatively low in these regions when compared with Belo Horizonte, which attracts population.

Figure 10 New bank branches, 2007-2015

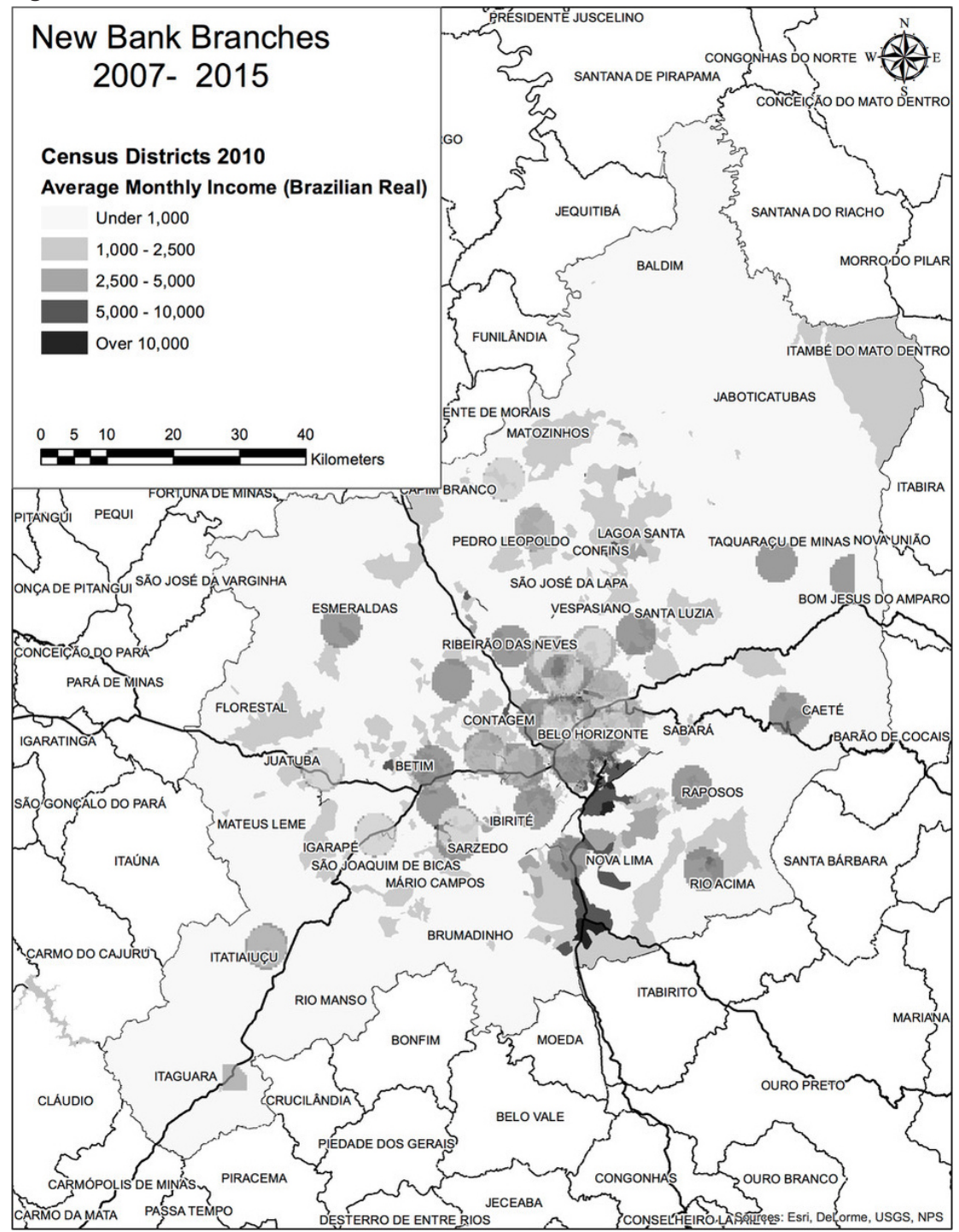

Source: Central Bank of Brazil (2007, 2015) and IBGE (2010).

Therefore, from this preliminary analysis, two specific patterns of growth in banks branches and posts can be derived, as seen in Figure 12 From 
the spatial position of CBD and given significant localization issues (path dependency), the establishment of new branches follows a radius pattern. Meanwhile, banks' posts appear to follow a L-shaped (North and West) expansion pattern, which may be more closely related to the axes of population and income expansion in the $\mathrm{MRBH}$.

Figure 11 Bank posts and bank branches, downtown Belo Horizonte, 2010

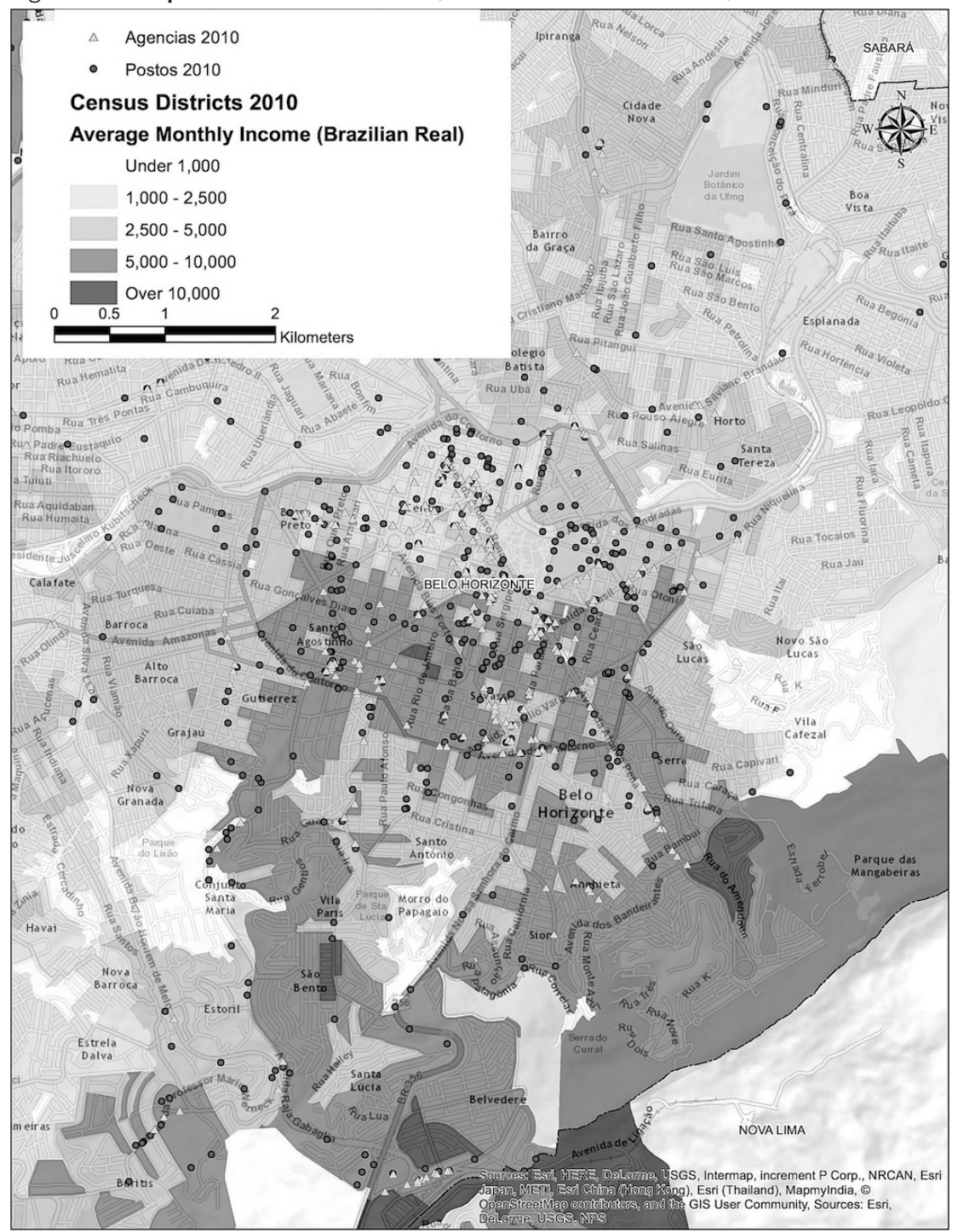

Source: IBGE (2010), Central Bank of Brazil (2015). 
Figure 12 Patterns of growth: new banks posts and branches

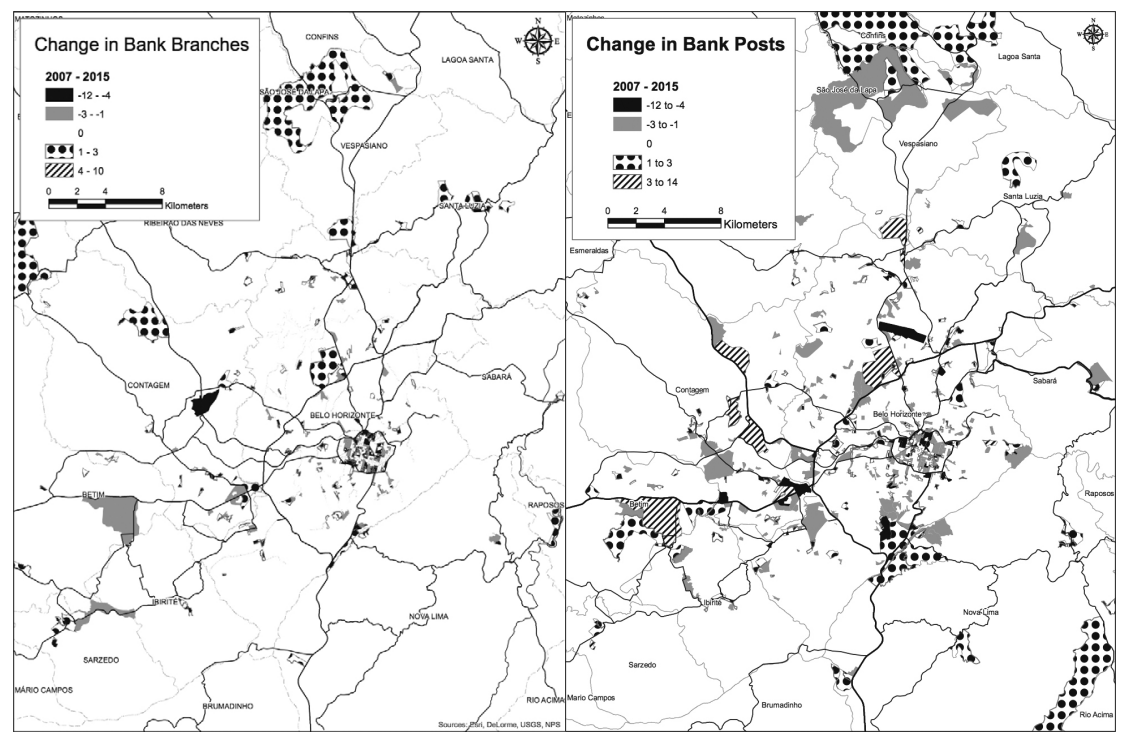

Source: Central Bank of Brazil (2015).

The last decade has shown new trends in the development of the metropolitan region that can be seen from the movement of banking services providers. Overall, Figure 12 shows a radial pattern of growth (green areas) from the CBD to the North, West and South of MRBH. A particular trend during this period was the dispersion of branches and posts, with a number of banks moving towards the north and south, areas that have been subject to large urban projects (the relocation of the State headquarters, from CBD to the North, and the consolidation of a high income real estate project in the south). In the west, it is fair to assume that municipalities of Contagem and Betim have already been transformed into a large conurbation with Belo Horizonte. However, the growing number of banks branches and posts in these places may foster local centralities. This phenomenon certainly illustrates urban structural changes stemming from overall Brazilian economic changes between 2003 and 2014. This period witnessed a significant drop in income inequality, which fostered the extension of a variety of services to poor people who were originally excluded from such services. In the case of Venda Nova (in the north), residents who previously lacked access to brick-and-mortar financial services now have more access to such services. On the other 
hand, a very recent move further to the South, with private development plans have not yet attracted as many banks' branches as expected given the local levels of income. The South of the metropolis, beyond Belo Horizonte borders, is occupied by high-income class in gated communities, which serve as holiday and weekend places of leisure. Banks have, so far, decided not to locate branches in these areas. High land rents, the characteristics of urban occupation (gated communities), and difficulties in access may be reasons for this pattern of banking location, associated with the proliferation of internet banking services. Nonetheless, the lack of services in these high-income suburban neighborhoods may be indicative of a problem to urban planning, resulting in an even more car-dependent transportation. Given the level of income, the families who live in gated communities of the metropolis may have more than two cars per family.

Finally, we have also carried out spatial correlation analyses in order to complement the above discussion. Figures 13 and 14 show spatial correlation in growth rates of banks' branches, posts, average income, and population in the boroughs of MRBH. The spatial patterns in Figure 13 may help understand possible growth trends in banks' branches, posts and centralities in the metropolitan region. The first two maps represent spatial correlation in banks' branches and posts growth. A general analysis indicates that in the CBD there are spaces with high growth while their neighbors present falling numbers of branches. Thus, if there is a pattern of concentration in the CBD, it is a decrease in the number of banks' branches in boroughs that are more distant from the CBD. Moreover, there is a high growth of branches in the Pampulha region, in the north sector of Belo Horizonte.

The figure for banks' posts is quite the opposite: growth has been significant in distant boroughs and their neighborhoods. One may conclude that banks are expanding their posts to more remote areas, while new branches have been predominantly located in the CBD. If such view is accredited, we have a dual perspective for the development of centralities in the MRBH: on the one side, banks posts are expanding, giving support for the formation of (new) centralities; however, on the other hand, banks' posts offer less complex services, therefore putting a limit on the capacity of the centralities to fulfill diverse demands for services by local agents. 
Figure 13 LISA: growth in banks' branches and posts
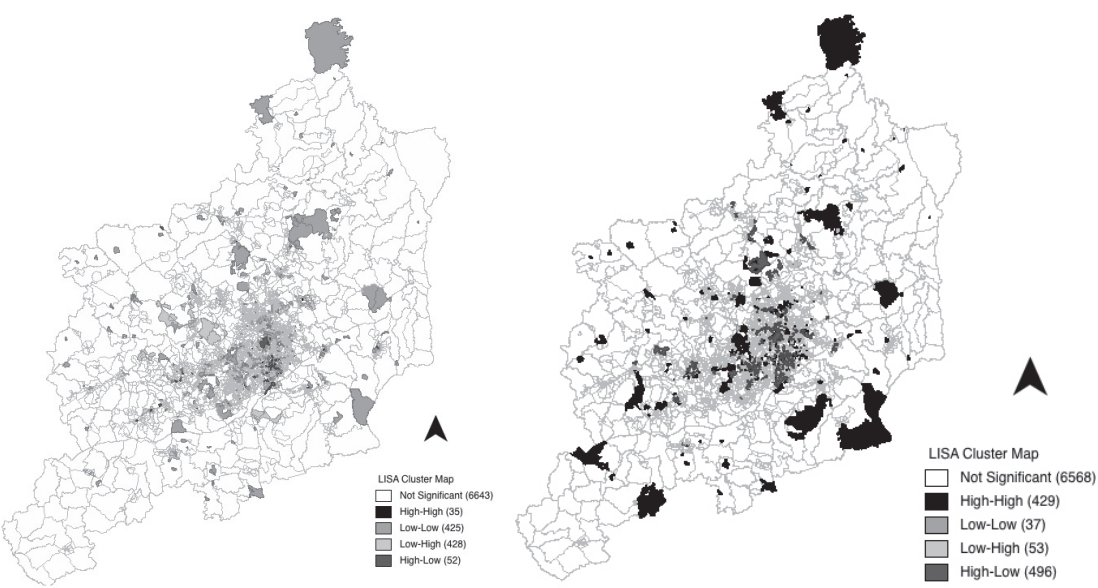

Source: Central Bank of Brazil (2015).

Figure 14 LISA: growth in population and income

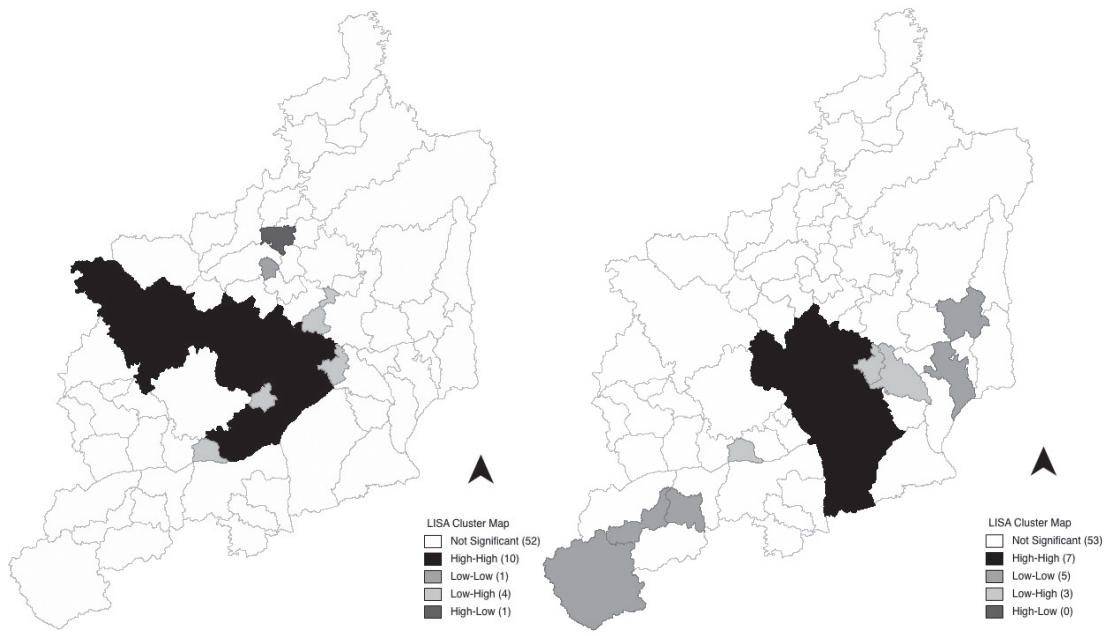

Source: IBGE $(2000,2010)$. Data on income and population were grouped in districts in order to reduce missing values between periods.

Lastly, the spatial analysis for correlation in income and population growth may help understand the directions of growth trends in the MRBH (Figure 14). As discussed above, the north and west axes of growth in banks' location might be correlated with population growth, which is highly spatially correlated. Concentration growth in the CBD (and to the south), however, 
may be geared towards income growth. More investigation is needed at this point. Nonetheless, it is fair to acknowledge that banks expansion is strategically diversified in terms of the complexity of services offered and their target audience, dynamically composing the different centralities in the metropolitan region.

\section{Conclusion: urban growth, financial centralities and urban planning}

Influence on the formation of urban spatial structure on the modern day metropolitan area overwhelmingly belongs to globalized market forces, even beyond the control of local and regional policy initiatives. One overarching urban pattern has become clear from both the literature and empirical analyses: the continued dominance of urban centralities and polycentric subcentralities while at the same time the ever increasing extension of population and services into the hinterlands. This growth both drives, and is driven by, access to financial capital and services. While technological and communication advances have changed consumer behavior, broadened mobile access to services, in a moment of more offers of financing for cars acquisition, access to financial services from brick-and-mortar establishments continues to be essential within urban markets. These trends result from economies of urbanization and other synergistic effects of spatial proximity. This is especially true for low-income populations who often lack access to mobile banking services yet are increasingly gaining access to services due to policies and market forces that reduced inequality during the past decade within developing economies.

The recognition and comprehension of such urban transformation, especially with regard to the formation of centralities and sub-centralities, becomes crucial for urban planning and development. First, it is paramount to understand the growth and development of the urban space and how urban sprawl can be conditioned to be more balanced in terms of access to services. The formation of new urban centralities is necessary in order to provide a more equitable city, or, more deeply, to ensure the right to the city for all citizens. Secondly, once the development of urban centralities is taken into consideration, other elements of urban planning can be better managed, such as land use and transportation systems. The formation of 
new urban centralities usually increases land value in neighboring areas, which requires a more careful examination by public institutions of the possibilities of land use in the affected areas. New urban centralities can impinge challenges for the administration of urban transportation, as traffic can be lessened in some areas or more intensified in others. Moreover, public policy must cope with the challenges raised by new suburban centralities, which may trigger processes of gentrification in some cases.

Thus, while considering policy implications to this work, it is clear that while the global market has transformed the urban and regional landscape, planning, policy, and metropolitan governance certainly have roles to play in creating livable, equitable, and sustainable communities, especially within the context of the neoliberal paradigm and the current instability in federal governing structures. The location of banking services providers may not be prone to strong public intervention, given that market forces are highly relevant in determining demand and supply for private and public banks. However, urban planners can better understand the dynamics of centralities when banking services dynamics are included. These services are significant components of any (sub)centrality in urban settings. Specifically, policies and planning that continue to promote access to overall services, in particular for marginalized populations within concentrations of poverty, have the potential to close the inequality gap and provide opportunities for traditionally isolated communities.

\section{References}

ABLAS, L. A Teoria do Lugar Central: bases teóricas e evidências empíricas. São Paulo: IPE/ USP, 1982.

ABRAMO, P. A Cidade Caleidoscópica: Coordenação Espacial e Convenção Urbana - uma perspectiva heterodoxa para a economia urbana. Rio de Janeiro: Bertrand do Brasil, 2007. $1^{\text {st }}$ ed.

ALMEIDA, R. Implosão e Explosão na Exópolis: Evidências a partir do Mercado Imobiliário da RMBH, 2015. Dissertação (Mestrado em Ciências Econômicas) - Cedeplar, Universidade Federal de Minas Gerais, Belo Horizonte, 2015.

ALMEIDA, R. From growth poles to Aerotropolis: state and large scale urban projects in the era of finance dominance. In: SEMINÁRIO SOBRE A ECONOMIA MINEIRA, 2016, Diamantina. Anais... Diamantina, Belo Horizonte: Cedeplar/UFMG, 2016.

ALONSO, W. Location and land use: Toward a general theory of land rent. Cambridge, MA: Harvard University Press, 1964. 
ARRIGHI, G. The long twentieth century: money, power and the origins of our times. London: Verso, 2004.

ASCHER, F. Metápolis ou l'avenir des villes. Paris: Odile Jacob, 1995.

ATLAS, DO D. H. NO B. Índice de Desenvolvimento Humano Municipal Brasileiro. Brasília: PNUD, Ipea, FJP, 2013.

BECATTINI, G.; RULLANI, E. Systéme local et marché global: le district industriel. In: RALLET, A.;TORRE, A. (Eds). Économie industrielle et économie spatiale. Paris: Economica, 1995.

BECKMANN, M. Location Theory, New York: Random House, 1968.

BENDER, T. City Lite. Los Angeles Times, 22 dez. 1996.

BERRY, B. Cities as Systems within Systems of Cities. Papers in Regional Science, v.1, n.13, p.147-163, 1964.

BERRY, B. and PRED, A. Central Places Studies: A Bibliography of Theory and Applications, Philadelphia: Regional Science Research Institute, 1961.

BENNETT, R. J. and GRAHAM, D. Explaining the size differentiation of business service centres. Urban Studies, v.35, n.9, p.1457-1480, 1998.

BETANCUR, J. Gentrification in Latin America: Overview and Critical Analysis. Urban Studies Research, v. 2014, p. 1-14.

BRENNER, N.; THEODORE, N. Spaces of Neoliberalism: Urban restructuring in North America and Western Europe. Oxford (UK) e Cambridge (MA): Blackwell Publishers, 2002.

BRUEGMANN, R. Sprawl: a compact history. Chicago: University of Chicago Press, 2005.

CARVALHO, F. Expectativas, incertezas e convenções. In: MONTEIRO, D.; PRADO, L.; LASTRES, H. (Orgs.). Estratégias de desenvolvimento, politica industrial e inovação: Ensaios em Memória de Fábio Erber. 1. ed. Rio de Janeiro: BNDES. p. 235-258, 2014

CASTELLS, M. The Informational Age: Economy, Society and Culture. Oxford: Blackwell Publishers, 1996.

CAVALCANTE, A. Regional Financial Development and Economic Growth, PhD Thesis, University of Cambridge, Cambridge, 2012.

CENTRAL BANK OF BRAZIL. Relação de Agências, Postos e Filiais de Administradoras de Consórcio, 2007. Available at http://www.bcb.gov.br/fis/info/agencias.asp Acessed in July, 2017.

CENTRAL BANK OF BRAZIL. Relação de Agências, Postos e Filiais de Administradoras de Consórcio, 2015. Available at http://www.bcb.gov.br/fis/info/agencias.asp Acessed in July, 2017.

CHRISTALlER, W. Central places in Southern Germany. Englewood Cliffs: Prentice Hall, 1933(1966).

CROCCO, M.; CAVALCANTE, A.; BARRA, C. The Behaviour of Liquidity Preference of Banks and Public and Regional Development: the Case of Brazil. Journal of Post Keynesian Economics, v.28, n.2, p. 217-40, 2005.

CROCCO, M., SANTOS, F., AMARAL, P. The Spatial Structure of the Financial Development in Brazil. Spatial Economic Analysis, v.5, pp. 181-293, 2010.

CROCCO, M.; SANTOS, F.; CAVALCANTE, A.; TEIXEIRA, M. Financial System Resilience: 
The Case of Brazil. In: REGIONAL STUDIES ASSOCIATION GLOBAL CONFERENCE, 2014, Fortaleza. UK: Regionl Studies Association, 2014.

CUADRADO-ROURA, J. The Location of Services Industry. In: CUADRADO-ROURA, J. (ed.) Service Industries and Regions: Growth, Location and Regional Effects, Springer-Verlag: Berlin, 2013.

CUENYA, B. Grandes Proyectos Urbanos y sus Impactos en La Centralidad Urbana. Cadernos Metrópole (PUCSP), v. 13, n. 25, p.185-212, 2011.

DERYCKE, P-H. Espaces et dynamiques territoriales. Paris: Economica, 1992.

DUMÉNIL, G.; LEVY, D., Costs and benefits of neoliberalism: A class analysis. Review of International Political Economy, v. 8, n.4, p.578-607, 2001.

DYMSKI, G.; KALTENBRUNNER, A. Beyond Europe's financial Bifurcation Point: Policy Proposals for a more stable and more equitable Financial System. FEPS Economic Policy Brief, n.4. Foundation for European Progressive Studies, 2014.

FIGUEIREDO, A. Uma abordagem pós-keynesiana para a teoria da localização: análise da moeda como um fator determinante na escolha locacional das empresas. Tese (Doutorado em Ciências Econômicas), Cedeplar, Universidade Federal de Minas Gerais, Belo Horizonte, 2009.

FISHMAN, R. Más alla de suburbia: el nacimiento del tecnoburbio. Lo Urbano. 1. ed. Barcelona: UPC, 2004. p. 35-48.

FIX, M. São Paulo cidade global: fundamentos financeiros de uma miragem. São Paulo: Boitempo, 2007. $1^{\text {st }}$ ed.

FLYVBJERG, B. What You Should Know About Megaprojects and Why: An Overview. Project Management Journal, v. 45, n. 2, p. 6-19, 2014.

FRIEDMANN, J. A General Theory of Polarized Development. In: HANSEN, N. (Ed.), Growth Centers in Regional Economic Development, New York: The Free Press, 1972.

GARREAU, J. Edge City: Life on the New Frontier. New York: Anchor Books, 1991. $1^{\text {st }}$ ed.

GLAESER, E.; GOTTLIEB, J. The wealth of cities: Agglomeration economies and spatial equilibrium in the US. Journal of Economic Literature, v.47, n.4, p.953-1028, 2009.

GILLHAM, O. The limitless city: A primer on the urban sprawl debate. 1. ed. Washington D.C.: Island Press, 2002.

GOLDSTEIN, G.; MOSES, L. A survey of urban economics. Journal of Economic Literature, v.11, n.2, p.471-515, 1973.

HARVEY, D. The Enigma of Capital and the Crises of Capitalism. London: Profile Books, 2010.

HARVEY, D. Cities or Urbanization? In: BRENNER, N. (Ed). Implosions/Explosions: Towards a Study of Planetary Urbanization. Berlin: Jovis, 2014. 576p.

HENDERSON, J. The sizes and types of cities. American Economic Review, v.64, n.4, pp. 640656, 1974.

HOLLAND, S. Capital versus the Region. UK: Palgrave MacMillan, 1976.

IBGE. Censo Demográfico. Rio de Janeiro: IBGE, 2000.

IBGE. Censo Demográfico. Rio de Janeiro: IBGE, 2010. 
IPEAD. Pesquisa de Alugueis. Belo Horizonte: IPEAD/FACE/UFMG, 2012.

JACOBS, J. The Economy of Cities. Middlesex: Penguin Books, 1969.

KASARDA, J. The Rise of the Aerotropolis. The Next American City, v. 10, p.35-7, 2006.

KASARDA, J. and LINDSAY, G. Aerotropolis: The Way We'll Live Next? New York: Farrar, Straus and Giroux, 2011. $1^{\text {st }}$ ed.

KOOLHAAS, R. and MAU, B. Small, medium, large, extra-large: office for metropolitan architecture. New York: Monacelli, 1995. $1^{\text {st }}$ ed.

LANG, R. Edgeless cities: exploring the elusive metropolis. 1. ed. Washington D.C.: Brookings Institution, 2003.

LANGLEY, P. Uncertain subjects of anglo-american financialization. Cultural Critique, v.65, n.1, p. 67-91, 2007.

LEAMER, E. A Flat World, a Level Playing Field, a Small World After All, or None of the Above? A Review of Thomas L. Friedman's The World is Flat. Journal of Economic Literature, v.45, n.1, p.83-126, 2007.

LEFEVBRE, H. The Production of Space. Oxford (UK): Blackwell, 1991(1974).

LÖSCH, A. The economics of location. New Haven: Yale University Press, 1941(1954).

LOWRY, I. A model of a metropolis. Santa Monica: Rand Corporation, 1964.

MAILLAT, D. Territorial dynamic, innovative milieus and regional policy. Entrepreneurship and Regional Development, v.7, n.2, p. 157-165, 1995.

MULLER, P. The Outer City: Geographical Consequences of Urbanization of the Suburbs. Association of American Geographers Resource Papers, n. 75-2, p. 2-75, 1976.

MYRDAL, G. Economic Theory and Underdeveloped Regions. London: University Paperbacks, 1957.

NORTH, D. Location Theory and Regional Economic Growth. Journal of Political Economy, v.63, n.3, p.243-258, 1955.

PALMA, G. The revenge of the market on the rentiers: Why neo-liberal reports of the end of history turned out to be premature. Cambridge Journal of Economics, v. 33, n.4, p. 829-869, 2009.

PARR, J. The Law of Market Areas and the Size distribution of Urban Centers. Papers in Regional Science, v.76, n.1, p.43-68, 1997

PARR, J. The Location of Economic Activity: Central Place Theory and the Wider Urban System. In McCANN, P. (Ed.) Industrial Location Economics, Cheltenham: Edward Elgar, 2002a.

PARR, J. Agglomeration Economies: ambiguities and confusions. Environment and Planning A, v.34, n.4, p. 717-731, 2002 b.

PARR, J. Perspectives on the City-Region. Regional Studies, v.39, n.5, p.555-566, 2005.

PARR, J.; BUDD, L. Financial Services and the Urban System: An Exploration. Urban Studies, v.37, n.3, p.593-610, 2000.

PRIKE, M.; GAY, P. Take an issue: cultural economy and finance. Economy and Society, v. 36, n.3, p.339-354, 2007.

PORTER, M. The Competitive Advantage of Nations. New York: Free Press, 1990. 
RICHARDSON, H. Optimality in City Size, Systems of Cities and Urban Policy: a Sceptics View. Urban Studies, v.9, n.1, p.29-48, 1972.

ROLNIK, R. Late Neoliberalism: The Financialization of Homeownership and Housing Rights. International Journal of Urban and Regional Research, v.37, n.3, p.1058-1066, 2013.

ROLNIK, R. Guerra dos Lugares: a colonização da terra e da moradia na era das finanças. São Paulo: Boitempo. 2015. $1^{\text {st }}$ ed.

SASSEN, S. The Global City: New York, London, Tokyo. Princeton, New Jersey: Princeton University Press. 1991. $2^{\text {nd }}$ ed.

SCOTT, A. Industrial organization and location: division of labor, the firm, and spatial process, Economic Geography, v.62, n.3, p.215-231, 1986.

SOJA, E. Postmetropolis: A Critical Study of Cities and Regions. Malden, MA: Blackwell Publishers, 2000.

SOJA, E. W. Para Além de Postmetropolis. Revista da Universidade Federal de Minas Gerais, v. 20 , n. 1, p. 137-167, jun. 2013.

SUDJIC, D. The 100 Mile City. London: André Deustch, 1992.

THRIFT, N. On the Social and Cultural Determinants of International Financial Centres: The Case of The City of London. In: CORBRIDGE, S.; MARTIN, R. (Eds.) Money, Power and Space, Oxford: Blackwell, 1994.

UFMG. Macrozoneamento da Região Metropolitana. Cedeplar: Belo Horizonte, 2014.

VON THÜNEN, J. Der Isolierte Staat in Beziehung auf Landwirtschaft und Nationalökonomie. Berlin: Wiegardt, Hempel \& Parey, 1826(1875). $3^{\text {rd }}$ ed.

\section{About the authors}

Anderson Cavalcante-atmc@cedeplar.ufmg.br

Professor adjunto no Centro de Planejamento e Desenvolvimento Regional, Universidade Federal de Minas Gerais, Belo Horizonte, Minas Gerais.

Renan P. Almeida - renanp.almeida@gmail.com

Doutorando no Centro de Planejamento e Desenvolvimento Regional, Universidade Federal de Minas Gerais, Belo Horizonte, Minas Gerais.

NathanielBaker-nbaker@clarionassociates.com

Clarion Associates, Chapel Hill, North Carolina.

The authors would like to thank FAPEMIG (grant n. CSA - APQ-01193-14) for the financial support during research. The authors would also like to thank the anonymous referee for useful comments and suggestions. The usual disclaimer applies.

\section{About the article}

Submission received on March 22, 2017. Approved for publication on June 29, 2017. 